\title{
Agronomic Performance and Nutritive Value of Mucuna Legume (Stilozobium Deeringianum (Bort) Merr.) as Influenced by Cutting Dates in Peruvian Central Coast
}

\author{
D. Escudero ${ }^{1}$, M. G. Echevarria² \& y E. D. Malpartida ${ }^{2}$ \\ ${ }^{1}$ Food and Agriculture Organization, Peru \\ ${ }^{2}$ Universidad Nacional Agraria la Molina, Peru \\ Correspondence: M. G. Echevarria, Universidad Nacional Agraria la Molina, Peru.
}

Received: August 5, 2020; Accepted: August 14, 2020; Published: August 19, 2020

\begin{abstract}
The agronomic performance and nutritive value of Mucuna legume (Stilozobium deeringianum (Bort) Merr.) at five different cutting days (DAS) were evaluated under agro-climatic conditions of Peruvian central coast to determine the optimum date for forage production. The experiment was carried out following a RCBD with five treatments in three replications. It came out that the optimum cutting date was 84 days after planting (DAP) with $25,633 \mathrm{~kg}$. ha- 1 of fresh matter and $6,422.6 \mathrm{~kg}^{-1} \mathrm{ha}^{-1}$ of dry matter. This corresponded to dry matter digestibility contents of $14.9,44.8,33$ and $66 \%$ in terms of crude protein, neutral detergent fiber and acid detergent fiber, respectively. Net energy for lactation obtained reached $1.43 \mathrm{Mcal} \cdot \mathrm{kg}^{-1}$. High forage yield with a great nutritive value obtained showed that Mucuna was well adapted to Peruvian Central Coast.
\end{abstract}

Keywords: forage legume, fresh yield, dry matter, digestibility, net energy, lactation

\section{Introduction}

Soil fertility is declining in Peru central coast due to excessive use agrochemicals at the expense of green manure. Therefore, the development of sustainable agricultural practices based on an integrated system of crop and livestock production might be highly beneficial. Legume forage, through biological nitrogen, is an economic source of protein with a good digestibility for cattle in the tropics (Herrera, 1966). Mucuna legume, as a tropical trailing forage which could be an alternative for soil fertility and forage improvement the agronomic and nutritional characteristics as a soil improvement and provide forage to livestock. Mucuna is not well spread in Peru in contrast of other South American countries where it is commonly grown as cover crop for soil fertility improvement as well as legume forage for cattle (Merayo, 2000).

The study aimed to determine the optimum date cutting Mucuna legume forage in Peru central coast.

\section{Materials and Methods}

\subsection{Characteristic of the Experimental Site}

Experimental plots were established in a San Francisco farm with loam soil that is located in Andahuasi district, Huaura province, Lima department, Peru (latitude $11^{\circ} 07 \mathrm{~S}$, longitude $77^{\circ} 12 \mathrm{~W}$, ), $425 \mathrm{~m}$ a.m.s.l. The average annual temperature reaches $22^{\circ} \mathrm{C}$, with 29.5 and $14.5^{\circ} \mathrm{C}$ as maximum and minimum daily values. Chemical analyses of plant samples were performed in the laboratory of Nutrition Department (University of Peru - UNALM).

\subsection{Mucuna Legume Characteristics}

It growths vigorously from sea level to $1,600 \mathrm{~m}$ above sea level, temperatures from $19^{\circ} \mathrm{C}$ to $28^{\circ} \mathrm{C}$, better adapted to fertile soil, neutral pH and is not tolerant to drought (Skerman et al., 1991). Mucuna has slow start that is improved if is cultivated in one to two lines. The optimum age to harvest for animals was 4 to 5 months (Bogdan and Skerman, 1997) In Australia forage yield of this forage was 17.4 ha- 1 with $15.6 \%$ crude protein. The same yield was obtained in Brazil with $18 \%$ crude protein. In other countries crude protein ranges from $10.4 \%$ to $18 \%$ and digestible dry matter was $50 \%$. In Mucuna hay crude protein varies from $12.9 \%$ to $17.8 \%$ and digestible protein varies from $7.1 \%$ to $10.8 \%$ (Skerman et al., 1991). 


\subsection{Establishment Experimental Plots}

Experimental plots were previously bare fallow two weeks before then were soil loosening and fallowed to be ready for seeding. Mucuna seeds were sowed manually with $0.8 \mathrm{~m}$ between furrows and $0.4 \mathrm{~m}$ between plants previously inoculated with bacteria (Rhizobium spp). After establishment land was divided into five sectors to avoid pendent, each sector has five equal dimension. The evaluated ages were: $21,42,63,84$ and 105 days that were applied to each plots in the three sectors.

Cropping growth, plant cover percentage, green yield and dry matter yield and crude protein, neutral detergent fiber, acid detergent fiber, in vitro dry matter digestibility and net energy for lactation were evaluated in each age. Cropping growth was determined taking five plants by random from soil level to terminal bud. Plant cover percentage was determined using square meter sampler of $1 \mathrm{~m}^{2}$ area divided in 25 squares of $0.20 \times 0.20 \mathrm{~m}$. in each period of evaluation- This square was placed in the central lines of plots to determine the apparent cover proportion of crop particles plant. Cover percentage was estimated addend values obtained from each particles multiplied by four. Fresh forage yield was determined by weighing plant samples collected in a $1 \mathrm{~m}^{2}$ area from each plot. Dry matter percentage was determined by taking a $250 \mathrm{~g}$ samples placed in an oven with $60^{\circ} \mathrm{C}$ for $48 \mathrm{~h}$ then were weighed.

Crude protein (CP) concentration was determined by Kjeldahl method (AOAC, 1990). Neutral detergent fiber (NDF) and acid detergent fiber (ADF) concentrations were determined by Van Soest technique (Goering and Van Soest, 1970). Dry matter in vitro digestibility was determined by Tilley and Terry technique (1963) modified by Van Soest (Goering and Van Soest, 1970). Net energy for lactation was estimated by Equation given by American Feed manufacturers Association (AFMA, 1981) and University of Illinois using ADF percentage.

Net energy for lactation for $\left(\mathrm{Mcal} \mathrm{Kg}^{-1} \mathrm{MS}\right)=2.302-0.0262 \mathrm{x} \% \mathrm{FDA}$

Crop growing data, forage yield, crude protein, neutral detergent fiber, acid detergent fiber in vitro dry matter digestibility were expressed in $\mathrm{kg}$. Ha- $1 \mathrm{dia}^{-1}$ and lactation net energy was expressed in $\mathrm{MJ} \mathrm{Ha}^{-1} \mathrm{day}^{-1}$ to calculate the statistical analysis in order to determine the optimum harvested age

\subsection{Experimental Design}

The experiment was set up following a randomized complete block design with five treatments consisting of Mucuna forage cutting dates in terms of days after sowing (DAS), in three replications. All dates were the following: 21, 42, 63 and 105 DAS.

\subsection{Statistical Analyses}

The comparison of treatment means, regarding each agronomic criterion investigated, was made using the analysis of variance (ANOVA). When significant F-values were detected, differences between individual means were determined using the Duncan test (Steel and Torrie, 1979).

\section{Results and Discussion}

\subsection{Agronomic Performance of Mucuna Legume}

The highest plant height was obtained on 105 DAS while the maximum crop growth rate of $5.70 \mathrm{~cm} /$ day was reached on 63 DAS (Table 1). Similarly, the highest mucuna crop cover rate $(100 \%)$ was observed on 84 DAS in line of findings reported by CIIDICCO (1991). Moreover, 50\% flowering rate of Mucuna was obtained on 84 DAS which much less than 100 DAS reported by Merayo (2001). Therefore, data showed the precocity and vigor of Mucuna legume in central coast of Peru in line of findings reported by Skerman et al. (1991).

Table 1. Agronomic performance of Mucuna forage in Peru central coast as influenced by cutting date.

\begin{tabular}{cccccc}
\hline $\begin{array}{c}\text { Crop age } \\
(\mathrm{DAS})\end{array}$ & $\begin{array}{c}\text { Crop heigth } \\
(\mathrm{m})\end{array}$ & $\begin{array}{c}\text { Growth rate }(\mathrm{cm} \\
\left.\text { day }^{-1}\right)\end{array}$ & $\begin{array}{c}\text { Crop cover } \\
(\%)\end{array}$ & $\begin{array}{c}\text { Forage fresh yield } \\
\left(\mathrm{kg} \mathrm{ha}^{-1}\right)\end{array}$ & $\begin{array}{c}\text { Forage dry Yield } \\
\left(\mathrm{kg} \mathrm{ha}^{-1}\right)\end{array}$ \\
\hline 21 & 0.24 & $1.16^{\mathrm{a}}$ & $19.20^{\mathrm{a}}$ & 900.00 & 272.60 \\
42 & 0.98 & $3.51^{\mathrm{b}}$ & $60.60^{\mathrm{b}}$ & 5250.00 & 1266.62 \\
63 & 2.17 & $5.70^{\mathrm{c}}$ & $98.90^{\mathrm{c}}$ & 12283.33 & 2946.42 \\
84 & 2.30 & $0.59^{\mathrm{a}}$ & $100.00^{\mathrm{c}}$ & 25633.00 & 6422.63 \\
105 & 2.43 & $0.63^{\mathrm{a}}$ & $100.00^{\mathrm{c}}$ & 32666.66 & 9326.00 \\
\hline
\end{tabular}

a,b,c Means with same letters in same column are not statistically different $(\mathrm{P} \geq 0.05)$; DAS (number of days after sowing). 


\subsection{Chemical Composition of Forage}

The crude protein concentration decreased markedly with age. Greater diminished were observed in the first 63 days, then these concentrations were stable from 84 days to 105 days (Table 2). This tendency is normal in any forage in relation to age (Johnson, 1972). At the 84 days and fifth percent floration Mucuna had $14.97 \%$ of crude protein which was similar to previous reports (Skermman et al. 1991, but this content was superior to Centrocema pubescens and similar to Dolichos lablab and Phaseolus calcaratus (Bogdan y Skerman, 1997).

The NDF and ADF contents at 105 days were less than 84 days, these results were not agreed with normal tendency that those fibrous contents are larger with age in legumes (Skerman et al., 1991) the explanation may be in reports given by Merayo (2001) that Mucuna is a plant that vegetate for long time give birth new leaf and leaf sheets changing the proportion of leaf/shoot given less fibrous contents in older plants. In vitro dry matter digestibility were greater in older ages than younger ages that were agreed with normal tendency in forages. However this unexpected relation did not found at the forage NDF and digestibility which was highest with lower NDF content (Van Soest, 1983) probably to low indigestible content such as lignin and silica (Jhonson,1972).

Net energy for lactation is inversely related to ADF concentration. At the 84 days with fifty percentage floration Mucuna had $5.98 \mathrm{MJ}$ of EN kg-1 DM which is higher than ENL of alfalfa (5.77 $\mathrm{MJ} \mathrm{kg}^{-1} \mathrm{MS}$ ) at the same phenological stage (NRC, 1989).

Table 2. Bromatological performance of Mucuna forage in Peru central coast as influenced by cutting date.

\begin{tabular}{llllll}
\hline $\begin{array}{l}\text { Crop age } \\
\text { (DAS) }\end{array}$ & $\begin{array}{l}\text { CP } \\
(\%)\end{array}$ & $\begin{array}{l}\text { NDF } \\
(\%)\end{array}$ & $\begin{array}{l}\text { ADF } \\
(\%)\end{array}$ & $\begin{array}{l}\text { IVDDM } \\
(\%)\end{array}$ & $\begin{array}{l}\text { NEL }^{1} \\
\text { MJ kg-1}^{-1} \text { MS }\end{array}$ \\
\hline 21 & 27.45 & 28.80 & 21.70 & 81.19 & 7.24 \\
42 & 20.05 & 36.95 & 21.30 & 70.10 & 7.42 \\
63 & 18.50 & 42.70 & 31.20 & 68.27 & 6.19 \\
84 & 14.97 & 44.80 & 33.15 & 66.12 & 5.98 \\
105 & 14.29 & 40.90 & 30.68 & 55.26 & 6.27 \\
\hline
\end{tabular}

${ }^{1}$ Estimated from \% FDA (A. M. F.A, 1981); CP (Crude protein) ; NDF (Neutral detergent fiber) ; ADF (acid detergent fiber); IVDDM (in vitro digestibility of dry matter); NEL (net energy lactation).

\subsection{Forage Dry Matter Digestibility}

The maximum accumulative rates of dry matter of Mucuna were obtained in the age between 63 to 84 days with $165.53 \mathrm{~kg} \mathrm{ha}^{-1} \mathrm{day}^{-1}$. This value was greater compare to 21,42 and 63 day evaluation. However it was similar in relation a 105 days age (Table 3). In the same way the maximum accumulation of produced crude protein was obtained in the age of 63 to 84 days ( $19.81 \mathrm{~kg}$ of PC ha- $\left.\mathrm{day}^{-1} \mathrm{ha}^{-1}\right)$. Likewise the digestible dry matter produced in ages 63 to 84 days was $106.27 \mathrm{~kg} \mathrm{ha}^{-1}$ day $^{-1}$ greater than other evaluated ages. On the other side the net energy for lactation was $961.31 \mathrm{MJ} \mathrm{ha}^{-1} \mathrm{day}^{-1}$ this value corresponded to 84 day age, It was greater than net energy found in the 21, 42 and 63 ages.

Data presented in this study showed that the maximum efficiency of dry matter, crude protein, digestible dry matter and net energy for lactation corresponded to 84 days that was the optimum cutting age. Further than this age decreased production of dry matter, crude protein, digestible dry matter and net energy for lactation furthermore Mucuna became more indigestible due higher fibrous contents.

Table 3. Nutritional quality of Mucuna forage in Peru central coast as influenced by cutting date.

\begin{tabular}{ccccc}
\hline $\begin{array}{c}\text { Crop age } \\
(\text { DAS })\end{array}$ & $\begin{array}{c}\text { Dry matter } \\
\left(\mathrm{kg} \mathrm{ha}^{-1} \text { day }^{-1}\right)\end{array}$ & $\begin{array}{c}\text { Crude protein } \\
\left(\mathrm{kg} \mathrm{ha}^{-1} \text { day }^{-1}\right)\end{array}$ & $\begin{array}{c}\text { IVDDM } \\
\left(\mathrm{kg} \mathrm{ha}^{-1} \text { day }^{-1}\right)\end{array}$ & $\begin{array}{c}\text { NEL } \\
\left(\mathrm{MJ} \mathrm{ha}^{-1} \mathrm{day}^{-1}\right)\end{array}$ \\
\hline 21 & $12.98^{\mathrm{a}}$ & $3.59^{\mathrm{a}}$ & $10.57^{\mathrm{a}}$ & $93.97^{\mathrm{a}}$ \\
42 & $47.33^{\mathrm{a}}$ & $8.53^{\mathrm{ab}}$ & $31.74^{\mathrm{a}}$ & $345.85^{\mathrm{a}}$ \\
63 & $79.99^{\mathrm{ab}}$ & $13.89^{\mathrm{ab}}$ & $53,64^{\mathrm{a}}$ & $432.83^{\mathrm{a}}$ \\
84 & $165.53^{\mathrm{b}}$ & $19.81^{\mathrm{b}}$ & $106.27^{\mathrm{b}}$ & $961.31^{\mathrm{b}}$ \\
105 & $138.26^{\mathrm{b}}$ & $17.39^{\mathrm{b}}$ & $43.31^{\mathrm{a}}$ & $930.90^{\mathrm{b}}$ \\
\hline
\end{tabular}

$\overline{a, b, c}$ Average with same letters are not statistical different $(\mathrm{P}<0.05)$ 


\section{Conclusions}

The results showed that the optimum cutting date of Mucuna forage was on 84 DAS under agro climatic conditions of Peru central coast. The forage exhibited a vigorous growth with higher dry matter yield of a very good nutritional quality of $165.5 \mathrm{~kg} / \mathrm{ha} / \mathrm{d}$ and $106 \mathrm{~kg} / \mathrm{ha} / \mathrm{d}$ and $961 \mathrm{MJ} / \mathrm{ha} / \mathrm{d}$ ), respectively.

\section{References}

American Feed Manufactures Association. (1981). 41 The Semi-annual meeting, Lexington KY USA.

AOAC. (1980). Official methods of analysis, 15th ed. Washington DC USA. Association of Official Analytical Chemist.

Bogdan, A., \& Skerman, P. (1997). Pastos tropicales y plantas de forraje. FAO, Italia.

CENTRO INTERNACIONAL DE INFORMACION SOBRE CULTIVOS DE COBERTURA - CIIDICCO (1991). Informe técnico $\mathrm{N}^{\circ} 13$, Honduras.

Goering, H., \& van Soest, P. (1970). Forage fiber analysis USDA Handbook N 37.

Herrera, G., Lotero, J., \& Crowder (1966). Frecuencia de corte en leguminosas tropicales. Pastos y Forrajes 22(9), 473-483.

Jhonson, W. (1972). La Evaluación Nutritiva de Pastos. Misión Agrícola Carolina del Norte y Programa de forrajes, Universidad Nacional Agraria La Molina, Perú.

Merayo, M. (2001). El pasto Mucuna: cobertura para malezas. Revista para el manejo integrado de plagas. CATIE, Costa Rica.

National Research Council. (1989). Nutrients requirements of dairy cattle. Sixth Revised edition, USA.

Skerman, P., Cameron, D., \& Riveros, F. (1991). Leguminosas forrajeras tropicales. FAO Roma, Italia.

Steel, P., \& Torrie, H. (1979). Bioestadística. Principios y Procedimientos. $2^{\text {da }}$ ed. McGraw-Hill.

Tilley, J., \& Terry, R. (1963). A two-stage technique for the in vitro digestion of forage crops. J. British Grassland Society, 18, 104-111. https://doi.org/10.1111/j.1365-2494.1963.tb00335.x

van Soest, P. (1965). Symposium on factors influencing the voluntary intake in relation to chemical composition and digestibility. J. Animal Science, 24, 834-843. https://doi.org/10.2527/jas1965.243834x

van Soest, P. (1982). Nutritional Ecology of Ruminants. O. and Books. Corvallis, Oregon USA.

\section{Copyrights}

Copyright for this article is retained by the author(s), with first publication rights granted to the journal.

This is an open-access article distributed under the terms and conditions of the Creative Commons Attribution license (http://creativecommons.org/licenses/by/4.0/). 